\title{
The wealth of the Swedish peasant farmer class (1750-1900): composition and distribution
}

\author{
Erik Bengtsson ${ }^{1 * \star}$ and Patrick Svensson ${ }^{2}$ \\ ${ }^{1}$ Department of Economic History, Lund University, Sweden and ${ }^{2}$ Swedish University of Agricultural Sciences, Sweden \\ *Corresponding author. Email: erik.bengtsson@ekh.lu.se
}

\begin{abstract}
Using about 1,730 probate inventories, this article studies the wealth of peasant farmers in Sweden for the years $1750,1800,1850$ and 1900 . Average wealth grew rapidly, tripling over the nineteenth century, but it did not grow equally: the Gini coefficient for the farmers' wealth grew from 0.46 in 1750 to 0.73 in 1900 . Farmers who lived close to the major grain markets in Stockholm and the mining district of Bergslagen were wealthier than others, as were farmers on fertile plains and, in 1900, those living in coastal areas. Increased market access - in terms of cities and foreign demand - meant that farmers well placed in terms of geography and infrastructure benefited much more than farmers on what became the periphery. The diversity of farmers' wealth grew, as did their financial sophistication.
\end{abstract}

\section{Introduction}

The peasant farmer (in Swedish: bonde) is a uniquely important figure in Swedish history writing and self-understanding. ${ }^{1}$ While the modernisation of agriculture in Britain from the seventeenth century onwards entailed a concentration of ownership and polarisation between agrarian owners and workers (Allen, 1992), in Sweden the agrarian revolution was to a large extent carried out by peasant farmers (Svensson, 2001; Wiking-Faria, 2009). ${ }^{2}$ A string of important studies have explored the role of farmers in the development of agriculture and agricultural production (Herlitz, 1974; Gadd, 1983; Köll, 1983; Gadd, 2000), and the relative productivity on peasantoperated farms compared with that on estates (Svensson, 2001; Wiking-Faria, 2009). Another important question is the distribution of resources in agrarian society and between farmers, and how the distribution was affected by agrarian growth (Herlitz, 1974; Martinius, 1977; Isacson, 1979; Morell, 1980; Olausson, 2004; Lindström, 2008).

The living standards and inequality of the peasant farmers are interesting for several reasons. Before 1850, about 90 per cent of Swedes lived in the countryside, and four fifths of the rural families in 1750 held some land (Gadd, 2000); in other words, the peasant farmers were a key group in society. They have been seen as consumers for industrial goods, thus encouraging industrialisation as their wealth grew (Schön, 1979). In this interpretation, the farmers' standard of living becomes a key variable in understanding new consumption patterns and new markets for consumer goods. We may also inquire about the types of consumption and goods held in the countryside compared to the urban sector (Lilja, Murhem and Ulväng, 2007; Tengroth Ulväng, 2007).

From all these perspectives, it is useful to examine the living standards of peasant farmers in Sweden during the eighteenth and nineteenth centuries. How much did living standards improve, and how was progress distributed? Previous studies have been local in design (Herlitz, 1974; Isacson, 1979; Gadd, 1983; Lindström, 2008); the major contribution of the present article is that we study the Swedish peasant farmer class as a whole, using a nationally representative sample.

(C) The Author(s) 2019. This is an Open Access article, distributed under the terms of the Creative Commons Attribution licence (http:// creativecommons.org/licenses/by/4.0/), which permits unrestricted re-use, distribution, and reproduction in any medium, provided the original work is properly cited. 
Our data include more than 400 probate inventories for farmers for each of the benchmark years $1750,1800,1850$ and 1900 . The data include all types of wealth, not only land but also personal items such as clothing, furniture and tools. We analyse the overall development as well as the regional distribution, and we also have an especially detailed sample of 120 active farmers from four well-located areas in 1800 and 1900 . Using the detailed sample we can make a very finegrained analysis of all the types of wealth.

\section{Peasant farmers and their society (c. 1750-1900)}

The eighteenth century is typically seen as the epoch of the rise of the Swedish peasant farmer class (Gadd, 2000: 195). Their tax burden lessened as the amount of land tax was fixed in relation to a given piece of land, and this meant that, with growing production, the proportion paid in tax declined (Herlitz, 1974; Gadd, 2000: 197-8; Olsson, 2005). From 1719 tenants of the Crown obtained the right to buy the land they tilled (Heckscher, 1941: 217) and from 1789 farmers were given the right to buy historically noble, tax-exempt land. In 1700, about one third of arable land was owned by independent farmers (freeholders), one third by the nobility ( 0.5 per cent of the population), and one third by the Crown (Gadd, 2000: 16-17). In 1845, the freeholders' share of ownership of land had increased to about 60 per cent, the nobility's share had decreased to 17 per cent, while non-noble landlords owned 12 per cent, and the Crown retained only 11 per cent (Gadd, 2000: 204). ${ }^{3}$

Regarding the economics of peasant farming, the most important debate for our period is how active the peasant farmers were in the so-called agrarian revolution, when farm productivity increased, which took place in Sweden from c. 1750 to 1850 (Gadd, 2000). The older 'from above' view saw the nobility as very much the leaders of development, as initiators of supposedly important reforms, such as enclosures, and with returns to scale from the production on their manorial demesnes. The most recent research, however, stresses the entrepreneurial spirit of the peasant farmers and the gradually higher productivity of their farms rather than that of the manors (Svensson, 2006; Wiking-Faria, 2009; Olsson and Svensson, 2016). We might have expected rapidly growing wealth from 1750 to 1900 , but for our article the interesting question arises of whether the farmers participated as effectively as the nobles in this 'agrarian revolution' regionally, by type of locality (forest versus plains) as well as individually.

For southern Sweden, Olsson and Svensson (2010) argue that the nineteenth-century enclosures were a very important element in creating opportunities for investments and thereby in increasing income and wealth among farmers. Enclosures also led to a stratification of the peasant-farmer class since they were costly and initially richer farmers benefited more than poorer ones. However, the impact of enclosures has been questioned by studies performed on other regions (see, for example, Allen, 2009, ch. 3; Pfister and Kopsidis, 2015). These studies argue instead that it was the commercialisation of agriculture through demand for its produce that altered the incentives for farmers to change cropping rotations and to expand the cultivated area through converting meadows to arable land. Demand could come from both expanding cities but also from a growing share of the non-agricultural labour force in the countryside (Pfister and Kopsidis, 2015). Either way, since enclosures differed in timing between regions in Sweden and since access to markets differed initially and over time, regional differences in wealth among the peasant farmers are likely to have emerged or widened during the nineteenth century. A key task of this article is to capture the development of farmers' wealth and their within-class inequality in this very dynamic period of Swedish agriculture.

\section{Stratification and inequality}

During the eighteenth and nineteenth centuries, rural stratification changed momentously. Christer Winberg (1975) in an influential study of population growth and proletarianisation 
showed, using data from Wohlin (1909), that while in 1750 four-fifths of rural families were freeholders or tenant farmers, in 1870 this was true for only one half. The recruitment of the landless population came about through several different mechanisms. One was downward social mobility of farmers, particularly with tenants under the nobility being evicted when landlords created large capitalistic farms. On peasant-owned land, partible inheritance was the de jure legislation, but in reality farms were often kept intact, at least up until changing legislation and the nineteenthcentury enclosures that eased the splitting of farms. The sibling taking over the farm had to pay her/his siblings for their shares, but with growing population and rising prices of land, access to land became restricted even though farms were split to a higher degree. During the nineteenth century, these mechanisms meant that the custom that farmers' children were rural servants as a phase in the life cycle before inheriting a farm, changed into some of the children remaining rural servants for life (Lundh, 1999; Gadd, 2000: 80).

There are several studies of stratification within the peasant farmer class. The only one at a national level is Nils Wohlin (1912), who used poll-tax registers and registers of taxation values and found that from 1810 to 1900 the inequality of landholding grew substantially and continuously, mainly due to the increasing numbers of very small landholdings. ${ }^{4}$ Since the 1970 s there has been a stream of local studies which, as Sjöberg (2003) remarks, find increased differentiation over time. Among them we have Isacson (1979) on one parish in a protoindustrial area of central Sweden (Dalarna) from 1680 to 1860 with equalisation during the eighteenth century and then growing inequality after 1800; Ågren (1992) who found proletarianisation and differentiation, including the development of a class of wealthy farmers, in one agrarian district and one mining district in Dalarna from 1650 to 1850; Martinius's (1977) argument that major peasant farmers started to distance themselves from ordinary peasants in about 1830; and Olausson (2004) on western Värmland from the seventeenth century to the mid-nineteenth century, starting with relatively large inequality even in the seventeenth century, which increased in the eighteenth century and continued from 1800 yet more rapidly, with the growth of proletarian and semiproletarian groups. An exception to the tendency to find growing inequality is Lindstrom (2008), who studies a mid-Swedish parish from 1620 to 1820 and finds marked stratification, with wealthy farmers dominating the local community, but no actual increase in inequality within the class of landed peasants.

For Scania, the most southern province of Sweden, Bengtsson, Olsson and Svensson (2011) study both distribution of land and differences in actual production. Looking at thirty-six parishes from around 1700 up to 1935, using poll-tax registers for land and flexible tithes for production, its authors find that during the eighteenth century land distribution was becoming more equal, but inequality in production also grew somewhat. In the nineteenth century, after the enclosures, inequality rose, both in terms of land and in terms of production. Other studies of the same region have shown wide differences in the development of production that reflect natural conditions and property rights (Olsson and Svensson, 2010). It was above all in the fertile plains that production grew most rapidly and among the peasant farmers it was the freeholders who experienced the greatest increase in production. This resulted in a growing inequality not only in land but also in income between farmers.

\section{Data and methodology}

As noted above, the main limitation of most previous studies is that they are detailed studies of smaller localities. This has shed much light on Swedish rural society, but the problem is that they do not lend themselves easily to conclusions about the whole country. Unlike them, this article samples localities all over the country in order to derive conclusions that cover the entire class of Swedish peasant farmers. 


\section{To use probate inventories}

Our source is probate inventories. Probate inventories were made mandatory in Sweden in 1734 and were used to divide the estate among heirs, repay debts, and to pay a small estate tax ( 0.25 per cent) that contributed to poor relief (Kuuse, 1974; Markkanen, 1978; Lindgren, 2002). Because of these manifold uses, there were strong incentives to probate the deceased. In international comparisons, the Swedish probate inventories are very rich. They include all types of wealth, from real estate to loans to clothes and other minor properties. (For studies of Swedish farmers using probate inventories, see Kuuse, 1970; Isacson, 1979; Gadd, 1983; Erikson, 2018.)

The probate inventories are archived by rural judicial district, härad or tingslag. There were 282 such districts in Sweden and we have a sample of 32 of them. They were randomly sampled after a basic geographical stratification by population: we had seven districts from the populous south (Götaland), nine from middle Sweden (Svealand), and six from the less populous north (Norrland). We determined benchmarks from 1750, 1800, 1850 and 1900. In these years, we extracted twenty-five random probate inventories from the relevant districts; when there were too few inventories in the chosen year we completed the sampling by taking inventories from adjacent districts, so that we had in the end one hundred inventories for each district-pair in the sample. ${ }^{5}$ In addition to this, we used inventories from eight towns for the same years (one hundred inventories for each town) and inventories for the nobility, which were held in separate registers. In total, the sample consists of almost 5,000 inventories.

All the sampled individuals were classified in a class schedule based on their title and occupation (found either in the probate inventories or in church death books); in total sixteen social groups based on their titles and/or occupations. We then merged these into four main groups: the nobility, the bourgeoisie, the peasant farmers, and the workers and lower middle class. ${ }^{6}$ This article focuses on the peasant farmer group, which includes freeholders as well as tenants under the Crown or under the nobility. ${ }^{7}$ This meant that in total the sample included 522 farmers in 1750, 452 farmers in 1800, 387 farmers in 1850, and 369 farmers in 1900. Often these people are called 'bonde' (farmer) in the sources (probate inventories, death books), but sometimes they have other titles: commonly, 'married man', 'widower', 'wife'; when they do, we have inferred the social status from other economic information in the sources. Farmers could also be called 'ex-soldier' or in allusion to the tasks they performed in local society: 'church warden', 'local judge'. They could also be called 'proprietor', 'tenant', 'cultivator', etc. Overall, 'bonde' was common at the beginning of the period, transitioning to many instances of 'proprietor' in 1900, very closely corresponding to what we know about the changing language about farmers in this period (Aronsson, 1992: 312).

In the Swedish literature, the most discussed methodological issue in using probate inventories is the practice of evaluation (Erikson, 2018: 48). For real estate, taxation values were used, and the taxation values sometimes lagged market values. For 1750 this should not be an issue, but when market values rose significantly during the nineteenth century, the taxation values did not keep up with them. A major reform took place in 1861-2 and then the taxable value of rural real estate more than doubled overnight. Lindgren (2017), in a recent paper argues, from a comparison of taxation values and auction prices, that the market prices for rural real estate around 1850 were twice that of the taxable value. For urban real estate it had never been much of a problem and after the 1861-2 reform, the issue disappeared. Waldenström (2017, Appendix: 13-14, Table B2) discusses the same issue in his calculation of Swedish national wealth. He suggests a sales-totaxable-value price ratio for farms of 1.5 in $1810,1.45$ in 1850 and 1.2 in 1900 . We also use this adjustment, which seems reasonable. ${ }^{8}$

Predictably, the old and the wealthy are over-represented in probate inventories (Lindgren, 2002). For this reason, in our quantitative analysis, the inventories are adjusted to the age and social structure of the living population (see Bengtsson et al., 2018). 
Table 1. Within-class inequality and total inequality, Sweden (1750-1900)

\begin{tabular}{lllcc}
\hline & 1750 & 1800 & 1850 & 1900 \\
\hline Nobility & 0.75 & 0.70 & 0.87 & 0.87 \\
\hline Bourgeoisie & 0.78 & 0.82 & 0.89 & 0.90 \\
\hline Peasant farmers & 0.46 & 0.58 & 0.67 & 0.73 \\
\hline Workers and lower middle class & 0.70 & 0.63 & 0.70 & 0.73 \\
\hline Total & 0.76 & 0.80 & 0.8 \\
\hline
\end{tabular}

Source: Probate inventory database; see Bengtsson et al. (2018) for discussion. Sample adjusted for age and social group. Dependent variable is net wealth. Rural real estate values are adjusted upwards by 50 per cent in 1800 and 1850 and 20 per cent in 1900, following the discussion in section 3; the same adjustment is used in Tables 2-4.

\section{The composition of the härader}

The key natural-geographic divide for historical studies of Swedish agricultural history is the distinction between forest-dominated areas and plains-dominated areas (Gadd, 1983; Hoppe and Langton, 1994; Wiking-Faria, 2009). With more productive soil, the plains areas, found in the very south and in a band from the great Lake Vänern eastwards across Lake Vättern to the east coast and around Lake Mälaren stretching east to Stockholm, typically produced grain. Noble owners were more common there, particularly in the south and in the Mälaren area. Forestdominated areas had less productive soil and animal products and handicrafts were more important for its agrarian groups (Gadd, 2000: 23-42). The thirty-seven districts in the dataset include both plains and forested areas, and from all parts of the country. From the most fertile plains, the Västgöta plains, Östgöta plains, Scania and the areas around Stockholm, we have the Kullings district on the Västgöta plains, Skärkinds on Östgöta plains, Bara in Scania, and Lagunda in Uppland. We also have several districts with less fertile soil, which are much more forested, such as Hova in northern Västergötland, Vista in northern Småland, and so on.

\section{Analysis: wealth and its distribution (1750-1900) Inequality within the peasant farmer class}

Table 1 shows wealth inequality by social group for our four benchmark years. We use the common measure, the Gini coefficient, which takes a value between 0 and 1 where 0 means that all households have the same amount of wealth, and 1 means that one household has all the wealth. Inequality within the peasant farmer class is low in 1750 with a Gini coefficient of 0.46 . From then on it increases markedly: to 0.58 in $1800,0.67$ in 1850 and 0.73 in 1900.

Is this low or high inequality? Gadd (2011: 122) describes the Swedish peasantry in 1800 as 'relatively homogenous' in economic terms. Of course, the term 'relatively homogenous' is slippery - relative to what? The country that produced a very great deal of quantitative research on rural stratification in the nineteenth century is the United States, which like Sweden had a very significant peasant farmer class, in some regions at least. Atack and Bateman (1981) have found a Gini coefficient of 0.63 for the rural part of the northern United States in 1860. Unfortunately, they did not elaborate how much of this inequality consisted of inequality between farmers and how much depended on differences between propertied and non-propertied groups. Yang (1984) estimates Gini coefficients in 1860 for free farmers in the South and North of the US; for the South, he found a Gini coefficient of 0.48 while for the North it varied between 0.46 and 0.56 , depending on the wealth definition used. Soltow (1971) finds a Gini coefficient among farmers in Wisconsin in 1860 of 0.69 . To sum up, the distribution of wealth within the peasant farmer class in Sweden in 1750 and 1800 was roughly at the same level as among farmers in the United States in the 
Table 2. Inequality and wealth by region for peasant farmers and for all rural residents

\begin{tabular}{|c|c|c|c|c|}
\hline \multicolumn{5}{|c|}{ Peasant farmers } \\
\hline & Götaland & Svealand & Norrland & Sweden \\
\hline \multirow[t]{2}{*}{1750} & $0.46(0.41-0.51)$ & $0.62(0.36-0.87)$ & $0.41(0.34-0.47)$ & \multirow[t]{2}{*}{$342 \mathrm{kr}$} \\
\hline & $268 \mathrm{kr}$ & $515 \mathrm{kr}$ & $362 \mathrm{kr}$ & \\
\hline \multirow[t]{2}{*}{1800} & $0.58(0.55-0.62)$ & $0.64(0.58-0.71)$ & $0.58(0.50-0.66)$ & \multirow[t]{2}{*}{$413 \mathrm{kr}$} \\
\hline & $401 \mathrm{kr}$ & $497 \mathrm{kr}$ & $295 \mathrm{kr}$ & \\
\hline \multirow[t]{2}{*}{1850} & $0.67(0.63-0.71)$ & $0.69(0.63-0.75)$ & $0.58(0.51-0.66)$ & \multirow[t]{2}{*}{$667 \mathrm{kr}$} \\
\hline & $656 \mathrm{kr}$ & $715 \mathrm{kr}$ & $605 \mathrm{kr}$ & \\
\hline \multirow[t]{2}{*}{1900} & $0.74(0.67-0.81)$ & $0.68(0.57-0.79)$ & $0.68(0.59-0.77)$ & \multirow[t]{2}{*}{$1774 \mathrm{kr}$} \\
\hline & $1786 \mathrm{kr}$ & $2143 \mathrm{kr}$ & $1273 \mathrm{kr}$ & \\
\hline \multicolumn{5}{|c|}{ All rural residents } \\
\hline \multirow[t]{2}{*}{1750} & $0.67(0.64-0.70)$ & $0.73(0.70-0.75)$ & $0.49(0.47-0.50)$ & $0.68(0.67-0.70)$ \\
\hline & $305 \mathrm{kr}$ & $572 \mathrm{kr}$ & $275 \mathrm{kr}$ & $377 \mathrm{kr}$ \\
\hline \multirow[t]{2}{*}{1800} & $0.72(0.72-0.73)$ & $0.73(0.72-0.74)$ & $0.51(0.50-0.51)$ & $0.70(0.70-0.71)$ \\
\hline & $303 \mathrm{kr}$ & $402 \mathrm{kr}$ & $246 \mathrm{kr}$ & $319 \mathrm{kr}$ \\
\hline \multirow[t]{2}{*}{1850} & $0.77(0.77-0.78)$ & $0.80(0.79-0.80)$ & $0.77(0.76-0.78)$ & $0.78(0.78-0.78)$ \\
\hline & $477 \mathrm{kr}$ & $532 \mathrm{kr}$ & $408 \mathrm{kr}$ & $480 \mathrm{kr}$ \\
\hline \multirow[t]{2}{*}{1900} & $0.83(0.83-0.84)$ & $0.79(0.78-0.80)$ & $0.78(0.77-0.78)$ & $0.81(0.81-0.82)$ \\
\hline & $810 \mathrm{kr}$ & $733 \mathrm{kr}$ & $711 \mathrm{kr}$ & $770 \mathrm{kr}$ \\
\hline
\end{tabular}

Note: Calculations for peasant farmers on raw data; for all rural residents on data adjusted for age and social class. 95 per cent confidence intervals in parentheses. Wealth in 1800 prices using the consumer price index (CPI) from Edvinsson and Söderberg (2010). In 18005.7 kronor translated into $£ 1$ sterling (Edvinsson, 2010).

mid-nineteenth century. In 1850, however, within-class inequality was higher in Sweden. (As in the US of course, the total picture of rural inequality and landholding inequality looks quite different if we do not consider farmers only, but also plantation owners/estate owners at the top and landless workers at the bottom of the social structure.) Perhaps we should not be surprised that Swedish farmers were less equal than their counterparts in the US, given the 'frontier' nature of agriculture in the western part of the US. Unfortunately, it is very difficult to glean wealth inequality estimates for farmers in other European countries during the period investigated. ${ }^{9}$

There are good reasons to believe that there were significant regional differences. In Table 2 below we see the Gini coefficient per broad region: Götaland (the south), Svealand (middle Sweden) and Norrland (the north).

In 1750, Svealand's farmers, including those in the Stockholm region, were a more unequal group than their colleagues to the north and to the south. They were also wealthier, which accords well with Söderberg's (1993) emphasis on the greater degree of market activity in eastern Sweden, the central area of Svealand. Until 1900, however, inequality increased very rapidly in the north and the south, and by 1900 Götaland held the farmer class with most inequality. By then, farmers in Svealand were still wealthier than their peers in Götaland and Norrland but the former had closed in and diminished the gap substantially. Overall rural wealth was also highest in this southern part of the country. The early stratification process and the relative stagnation correspond closely to the East Swedish pattern discussed among others by Söderberg (1993). For rural society overall, it seems that inequality stagnates when overall wealth does so and that wealth grows faster 
as inequality increases, as many theories of historical inequality would argue (Van Zanden, 1995; Milanovic, Lindert and Williamson, 2011).

\section{The development of real wealth}

Column 4 of Table 2 shows the development of farmers' wealth from 1750 to 1900 in real prices. Wealth for the average farmer grew by 60 per cent from 1800 to 1850 and more than doubled from 1850 to 1900 , increasing by 101 per cent. Freeholders were overall wealthier than the average farmers, for obvious reasons, and their wealth grew a bit faster: from $660 \mathrm{kr}$ in 1800 to 1,073 $\mathrm{kr}$ in 1860 and $2,471 \mathrm{kr}$ in $1900 .{ }^{10}$ For all rural residents, including the peasant farmers, wealth grew slower during the nineteenth century and levels were of course lower than for the peasant farmer group itself. This indicates that the rising wealth was distributed unequally among the people living in the Swedish countryside. Previous results have shown that farmers' wealth relative to the whole population improved from 1750 to 1900 (Bengtsson et al., 2018).

Rural real estate, that is, land and buildings, was an important part of the wealth of the farmer group. In 1750, the farms represented on average 14.7 per cent of the farmer's wealth, and this grew over time, to 36.2 per cent in $1800,42.2$ per cent in 1850 and 39.3 per cent in 1900 . This calculation, however, includes tenants with zero value in rural real estate. So one reason for rural real estate to be a growing share of assets is, as discussed above, the increase in the proportion of peasant farmers becoming freeholders through buying former crown or noble land. However, the growing importance of land for overall wealth is not only due to wider ownership. Looking only at those who owned land, it was 38.5, 62.0, 70.3 and 68.1 per cent in the four benchmark years, respectively. The farms' growing share of wealth depended also upon the increasing prices of land: as land markets became freer (Dribe and Lundh, 2005; Svensson, 2013), and domestic and international demand for agricultural products grew, land prices grew. Land prices per mantal (the judicial unit) grew by 377 per cent from 1800 to 1850 and 303 per cent from 1850 to 1900, while the consumer price index 'only' grew by 146 per cent and 29 per cent respectively (Bengtsson et al., 2018, Table 5).

Clearly, then, real wealth increased and part of this was connected to land. Now, in Swedish historiography the peasant farmers played a role in the emerging home-based early industrialisation through specialising in agriculture and buying industrial products, for example, textiles and iron tools (Schön, 2012). To be able to say something about this we need to decompose wealth further. One way is to look at the wealth consisting of movables, which include both textiles and tools. It seems that the real value of movables increased on average by 40 per cent between 1800 and 1850 and by two and a half times in the period 1850 to 1900 . So, the increase was somewhat slower than for rural real estate but followed the same pattern. These results confirm and extend previous findings on the investment by peasant farmers in specific items. Both for western and southern Sweden, regional studies have shown that the farmers invested in means of transport (for example, better wagons containing iron parts) during the agricultural revolution (Gadd, 1983; Bergenfeldt, Olsson and Svensson 2013). The increased use of iron among the peasant farmers has also been found in a study by Per Hallén (2003). To explore this further, we will zoom in on certain regions and hundreds. ${ }^{11}$

\section{A regional and local focus on farmers' wealth}

\section{Regional analysis}

It may be assumed that the increase in real wealth was larger in certain geographical areas than in others. Two regions that stand out in this respect are the plains and the areas adjacent to large cities and commercial trade, the former due to their natural conditions, permitting surplus production and therefore increasing income (Olsson and Svensson, 2010): the latter due to demand 
Table 3. Net value and value of movables for farmers by region

\begin{tabular}{|c|c|c|c|c|c|c|c|}
\hline & Plains & Sthlm/Iron & Inland & Coastal & North & Woods & All \\
\hline \multicolumn{8}{|c|}{ Net value } \\
\hline \multirow[t]{3}{*}{1800} & 508 & 534 & 329 & 312 & 277 & 476 & 413 \\
\hline & $(347-668)$ & $(343-725)$ & $(241-417)$ & $(244-401)$ & $(165-389)$ & $(366-586)$ & $(359-468)$ \\
\hline & $N=59$ & $\mathrm{~N}=91$ & $\mathrm{~N}=66$ & $\mathrm{~N}=88$ & $\mathrm{~N}=50$ & $\mathrm{~N}=77$ & $\mathrm{~N}=448$ \\
\hline \multirow[t]{3}{*}{1850} & 463 & 752 & 657 & 574 & 605 & 883 & 668 \\
\hline & $(207-720)$ & $(468-1036)$ & $(289-1024)$ & $(392-755)$ & $(354-858)$ & $(602-1164)$ & (561-774) \\
\hline & $\mathrm{N}=55$ & $\mathrm{~N}=79$ & $\mathrm{~N}=50$ & $\mathrm{~N}=83$ & $\mathrm{~N}=39$ & $\mathrm{~N}=65$ & $\mathrm{~N}=381$ \\
\hline \multirow[t]{3}{*}{1900} & 1898 & 2440 & 1714 & 1513 & 1423 & 1621 & 1775 \\
\hline & $(595-3201)$ & $(1133-3746)$ & $(770-2658)$ & $(383-2645)$ & $(692-2155)$ & (999-2244) & (1351-2198) \\
\hline & $\mathrm{N}=61$ & $\mathrm{~N}=57$ & $\mathrm{~N}=55$ & $\mathrm{~N}=79$ & $\mathrm{~N}=50$ & $\mathrm{~N}=56$ & $\mathrm{~N}=369$ \\
\hline \multicolumn{8}{|c|}{ Movables } \\
\hline \multirow[t]{2}{*}{1800} & 200 & 210 & 162 & 140 & 199 & 150 & 176 \\
\hline & $(164-237)$ & $(164-256)$ & $(130-193)$ & $(97-183)$ & (149-249) & $(125-175)$ & $(160-192)$ \\
\hline \multirow[t]{2}{*}{1850} & 243 & 297 & 56 & 185 & 380 & 265 & 240 \\
\hline & $(132-355)$ & $(205-389)$ & $(-230-344)$ & $(140-230)$ & $(196-566)$ & $(197-333)$ & $(189-291)$ \\
\hline \multirow[t]{2}{*}{1900} & 658 & 1107 & 333 & 882 & 468 & 546 & 678 \\
\hline & (309-1009) & $(-83-2298)$ & $(126-540)$ & $(244-1522)$ & $(253-683)$ & (321-771) & $(440-917)$ \\
\hline
\end{tabular}

Note: This covers all peasant farmers. SEK in 1800 prices. 95 per cent confidence intervals in parentheses.

and commercial structures. Furthermore, Morell (2001: 84-108) stresses that the profitable export of butter from the 1880s was led by the southern parts of the country; the transition to dairy farming was evident in Norrland also, but there it was more often production for the local markets. Kuuse's (1970) study of the mechanisation of Swedish agriculture 1860-1910 shows that this process was much faster in Uppland County, close to Stockholm and in the southern Malmöhus County than in the inland forested region of Kronoberg County.

In accordance with this, we divide the sample into six different regions: (a) farmers on the plains, who would have benefited from the high quality of the soil; (b) farmers close to Stockholm and Bergslagen, the mining district, which was an important market for food products, who would have had the best local markets for their produce; (c) farmers in inland Sweden close to small towns; (d) farmers in coastal areas; (e) farmers in northern Sweden, who might suffer from the unfriendly climate (Gadd, 2000: 39-42); and finally (f) farmers in wooded areas. ${ }^{12}$ Table 3 shows the net value and movables for farmers in our six regions in 1800, 1850 and 1900, the period of growing rural wealth. Obviously, the confidence intervals are very broad since the sample for each region is small, but we believe that the estimates are still interesting. They should be seen as indicative, pointing forwards for further research.

As regards net wealth, the peasant farmers in the plains and the Stockholm area were indeed richer than their counterparts in other areas. However, surprisingly, the woodland farmers were almost as rich in 1800. And in 1900 the wealth of the inland farmers was not far from that among the farmers in the plains. Significantly, however, regional differences may be due to differences in land ownership and tenure. In certain districts, as in southern and central Sweden, the nobility owned large parts of the land and hence most peasant farmers were tenants, whereas in other parts 
freeholders dominated. Since rural real estate is a source of wealth, but not an indication of wealth accumulation derived from the consumption and potential demand for industrial products, we also look at movables.

In 1800, the plains and the Stockholm area had the highest level of wealth as measured by movables, and so, surprisingly, had northern Sweden. ${ }^{13}$ Here there are relatively large differences in the development over time; farmers in the Stockholm area, and particularly in coastal districts, showed the greatest increase of wealth in movables. In 1900, the farmers in the Stockholm area were the wealthiest in terms of movables, followed by coastal farmers, and those in the plains. This points to communications and trade as important factors in the peasant farmer's acquisition of movables but, of course, also, in part, to the possibilities of generating a surplus in agriculture. All six of our coastal hundreds are in the south of Sweden, five on the west coast and one on the east coast. The five on the west coast all had good connections by sea with the growing markets of the fast expanding industrial cities of Gothenburg and Malmö. At the beginning of the nineteenth century, farmers from this area were known as very poor (Löfgren, 1977); they migrated seasonally for work to the plains in the very south, or to the herring fisheries on the west coast (Utterström, 1957: 151-77). With urbanisation they evidently benefited from growing markets. More surprising is a relatively strong development during the nineteenth century among the forest area farmers. One possible factor is the development of forest-based industry (planks, pulp, paper) in the second half of the nineteenth century (Schön, 2012).

However, as can be seen in Table 3, the variation within each region is very wide, connected to the within-inequality in the peasant-farmer class. This makes the averages discussed above less certain and they should be treated with some caution. Still, the overall development of the regional differences, and the direction in wealth accumulation both between regions and over time fits well with the general economic development in the regions found in previous studies (Utterström, 1957; Söderberg, 1993).

To summarise: there were important regional differences in farmers' wealth and in their marketisation. In 1900, coastal farmers in the South had, on average, movables valued at 89 per cent more than their northern counterparts. The same year, the movables among plains farmers were almost twice as valuable (98 per cent) as the ones belonging to the inland farmers. This indicates rising wealth and rising inclusion in the consumption revolution among certain parts of the farmer class. In the very interesting locally focused previous literature on farmers' wealth (Isacson, 1979; Gadd, 1983; Lindström, 2008), this dimension is missing by design. Of course the regional inequality matters in a different way - it does not affect local power relations, which previous research has been rather interested in. But it is interesting as one aspect of total inequality, and helps us understand why the overall estimates of inequality, such as in Table 1, increased so much (Bengtsson et al., 2018).

\section{The development in four wealthy hundreds}

There are therefore clear regional differences in wealth accumulation, and to move further into what this accumulation consisted of we chose to look in more detail at the development in four hundreds (härader), which, due to their location and natural geography, could be expected to be expansive. Lagunda, north-west of Stockholm on the road between the towns of Uppsala and Enköping, is one of the hundreds representing the region close to the capital and lies between this and the highly commercialised mining area of Bergslagen. The second hundred is Sjuhundra härad, close to Stockholm, but north-east along the coastal way. The third hundred, Kullings, is on the western plains, close to the Gothenburg market and harbour, which exported to Britain. Finally, Bara hundred is in the south on one of the most fertile soils of the country and close to the city of Malmö, with the largest outward grain-shipping harbour in Sweden. For these four hundreds, we added to the original sample of peasant farmers to make a total of thirty inventories from active farmers ${ }^{14}$ for each hundred in each of the years 1800 and 1900 , covering 
the period of the agricultural revolution and the first industrial one. The share of land being noble, and therefore not eligible for ownership by a peasant farmer in 1800 is highest in Sjuhundra with 80 per cent, followed by Bara with around 50 per cent and in Kullings and Lagunda at around 40 per cent. This is reflected in our sample, where the number of farmers owning their farm was twelve in Sjuhundra in 1800 and fifteen in 1900, eighteen in Bara in 1800 and twenty-two in 1900, twenty-four in Kullings in 1800 and twenty-four in 1900 and twenty-one in Lagunda in 1800 and twenty-five in 1900. In other words, Lagunda and Kullings were freeholder-dominated areas, while in Sjuhundra and to some extent Bara, the nobility owned most of the land. Land distribution was partially affected by this but also by land productivity and the organisation of agricultural labourers. In the eastern Sweden hundreds (Lagunda and Sjuhundra) there was a large share of farmers with substantial landholdings as well as those with medium-sized landholdings but almost no smallholders. This did not change much from 1800 to 1900 . Agricultural workers lived mainly on crofts or were landless. In the case of Kullings, land was extremely equally distributed on medium-sized farms in 1800 but over time a growing share of smallholders emerged. In 1800 most farmers in Bara had large or medium-sized farms but in 1900 the share of smallholders had grown substantially and made up most of the farmers. This was due to two reasons: that high soil productivity allowed for the splitting of farms; and that agricultural labour to a large extent worked on very small farms, non-subsistence, forcing them to supplement their income by wage labour (Wohlin, 1911). Finally, although all four hundreds were situated on the plains, the share of arable land differed, due to natural conditions and soil quality. In Bara 76 per cent of the land was arable whereas this share was 53 per cent in Lagunda, 22 per cent in Sjuhundra and 21 per cent in Kullings (BiSOS, 1895). In the overall sample the share was 23 per cent.

This restricted sample is much more detailed and will thus help us understand the nuts and bolts of the transformation in the nineteenth-century farming economy. For these hundreds, we break down the general category of 'movables' into something much more fine-grained. We look specifically at the role of cash, gold, silver, brass, copper (including liquour distilling equipment), tin, iron, wooden products, bed linen, clothing, utensils, furniture, tools, books, animals, farming tools, and a residual category.

Table 4 shows basic facts about the 120 farmers in 1800 and in 1900 . Over the nineteenth century mean wealth grew by 429 per cent in Lagunda, 393 per cent in Sjuhundra, 1273 per cent in Kullings and 755 per cent in Bara. ${ }^{15}$ Compared to the national average wealth for farmers (Table 2) in 1800, Lagunda and Bara were about par with the national average, Sjuhundra was richer, and Kullings was much poorer. But in 1900, Sjuhundra and Kullings farmers were about 70 per cent wealthier than the national average, Lagunda 40 per cent richer, and Bara 2.3 times richer. This indicates the increasing regional disparity in the Swedish farmer class over this period of rapid agrarian growth, in line with the regional differences shown in Table 3. One factor that seems to lie behind this divergence is the development of land prices. Land prices grew significantly in nineteenth-century Sweden; (Bengtsson et al., 2019, Table 5) report what amounts to an increase in the price per mantal from 2,039 kr to $13,522 \mathrm{kr}$ in 1800 prices, or a real increase of 563 per cent. In Lagunda and Sjuhundra, land prices grew slower than this (in Sjuhundra from a level above the national average), but in Kullings and Bara they grew much, much faster. ${ }^{16}$ This should be related to the fact that Kullings was in the vicinity of Gothenburg, and was connected in the 1860s by railroad to this city and harbour, and that Bara was between the fast-growing towns of Lund and Malmö. The Stockholm region already had high levels of market integration in the early nineteenth century (for example, Erikson, 2018), but the western plains including Kullings lacked them; market integration came later there.

The category of movables is very wide, in that it includes consumer goods such as bed linen and furniture as well as what amounted to capital goods for the farmers: tools, animals, wagons, ploughs and harrows and the like, and grain. A division of movables into household goods and capital (or producer) goods shows that the former category's share of farmers' wealth declined 
Table 4. Development of farmer wealth in four hundreds (1800-1900)

\begin{tabular}{|c|c|c|c|c|c|c|c|c|}
\hline & & $\begin{array}{c}\text { Mean } \\
\text { wealth } \\
\text { (median) } \\
\text { Freeholders }\end{array}$ & $\begin{array}{c}\text { Mean } \\
\text { movables } \\
\text { Freeholders }\end{array}$ & $\begin{array}{l}\text { Average } \\
\text { share } \\
\text { movables }\end{array}$ & $\begin{array}{c}\text { Average } \\
\text { share real } \\
\text { estate } \\
\text { Freeholders }\end{array}$ & $\begin{array}{l}\text { Mean land } \\
\text { price, per } \\
\text { mantal } \\
\text { Growth \% }\end{array}$ & $\begin{array}{l}\text { Average } \\
\text { animal } \\
\text { value, } \\
\text { share }\end{array}$ & $\begin{array}{c}\text { Average } \\
\text { financial } \\
\text { value, share }\end{array}$ \\
\hline \multirow[t]{2}{*}{ Lagunda } & 1800 & $\begin{array}{c}470 \\
(216) \\
574\end{array}$ & $\begin{array}{l}255 \\
267\end{array}$ & $56 \%$ & $\begin{array}{c}40 \% \\
56.6 \%\end{array}$ & $\begin{array}{c}1,326 \\
(n=12)\end{array}$ & $\begin{array}{c}95 \mathrm{kr} \\
24 \%\end{array}$ & $\begin{array}{c}49 \mathrm{kr}, \\
5 \%\end{array}$ \\
\hline & 1900 & $\begin{array}{l}2,458 \\
(950) \\
2,807\end{array}$ & $\begin{array}{l}1,353 \\
1,234\end{array}$ & $40 \%$ & $\begin{array}{l}55 \% \\
66.5 \%\end{array}$ & $\begin{array}{c}7,762 \\
(n=24) \\
485 \%\end{array}$ & $\begin{array}{c}616 \mathrm{kr} \\
18 \%\end{array}$ & $\begin{array}{c}235 \mathrm{kr} \\
5 \%\end{array}$ \\
\hline \multirow[t]{2}{*}{ Sjuhundra } & 1800 & $\begin{array}{c}614 \\
(269) \\
1,273\end{array}$ & $\begin{array}{l}236 \\
302\end{array}$ & $69 \%$ & $\begin{array}{c}23 \% \\
57.2 \%\end{array}$ & $\begin{array}{c}2,537 \\
(n=10)\end{array}$ & $\begin{array}{c}78 \mathrm{kr} \\
29 \%\end{array}$ & $\begin{array}{c}127 \mathrm{kr} \\
8 \%\end{array}$ \\
\hline & 1900 & $\begin{array}{l}3,028 \\
(872) \\
5,612\end{array}$ & $\begin{array}{c}1,025 \\
968\end{array}$ & $60 \%$ & $\begin{array}{c}32 \% \\
64.9 \%\end{array}$ & $\begin{array}{c}9,271 \\
(n=15) \\
265 \%\end{array}$ & $\begin{array}{c}501 \mathrm{kr} \\
32 \%\end{array}$ & $\begin{array}{c}412 \mathrm{kr} \\
7 \%\end{array}$ \\
\hline \multirow[t]{2}{*}{ Kullings } & 1800 & $\begin{array}{c}220 \\
(130) \\
310\end{array}$ & $\begin{array}{l}134 \\
127\end{array}$ & $66 \%$ & $\begin{array}{c}26 \% \\
56.1 \%\end{array}$ & $\begin{array}{c}782 \\
(n=8)\end{array}$ & $\begin{array}{c}56 \mathrm{kr} \\
28 \%\end{array}$ & $\begin{array}{c}44 \mathrm{kr} \\
7 \%\end{array}$ \\
\hline & 1900 & $\begin{array}{c}3,022 \\
(1,286) \\
3,564\end{array}$ & $\begin{array}{l}654 \\
711\end{array}$ & $31 \%$ & $\begin{array}{c}56 \% \\
70.6 \%\end{array}$ & $\begin{array}{c}13,674 \\
(n=21) \\
16485 \%\end{array}$ & $\begin{array}{c}251 \mathrm{kr} \\
14 \%\end{array}$ & $\begin{array}{c}939 \mathrm{kr} \\
12 \%\end{array}$ \\
\hline \multirow[t]{2}{*}{ Bara } & 1800 & $\begin{array}{c}477 \\
(218) \\
875\end{array}$ & $\begin{array}{l}362 \\
412\end{array}$ & $78 \%$ & $\begin{array}{c}16 \% \\
59.5 \%\end{array}$ & $\begin{array}{l}3,667 \\
(n=3)\end{array}$ & $\begin{array}{c}132 \mathrm{kr} \\
33 \%\end{array}$ & $\begin{array}{c}83 \mathrm{kr} \\
6 \%\end{array}$ \\
\hline & 1900 & $\begin{array}{c}4,081 \\
(1,680) \\
5,203\end{array}$ & $\begin{array}{l}1,174 \\
1,027\end{array}$ & $35 \%$ & $\begin{array}{c}53 \% \\
71.9 \%\end{array}$ & $\begin{array}{c}49,630 \\
(n=20) \\
12534 \%\end{array}$ & $\begin{array}{c}553 \mathrm{kr} \\
16 \%\end{array}$ & $\begin{array}{c}524 \mathrm{kr} \\
13 \%\end{array}$ \\
\hline
\end{tabular}

Note: Thirty farmers for each hundred. All level variables are in 1800 prices. Growth (\%) is from 1800 to 1900 . Financial value includes both cash in hand, bank deposits and claims. Averages given in percentages are averages of all individual farmers' shares of each category.

steeply from 1800 to 1900 . In 1800 the share was 20 per cent in Lagunda, 29 per cent in Sjuhundra, 25 per cent in Kullings, and 31 per cent in Bara; in 1900 it had fallen to 9, 13, 10 and 8 per cent respectively. The share of capital goods held up better in the Stockholm area but fell in the south and west: from 33 to 31 per cent in Lagunda, from 39 to 47 in Sjuhundra, 41 to 21 in Kullings, and 48 to 25 in Bara. That it decreased in Kullings and Bara is of course related to the immense growth of land prices there. The farmers' stock of tools and farming machinery did however become richer and more advanced. ${ }^{17}$ The shares are low compared to those computed for Kent and Cornwall 1600-1749 by Overton (n.d.), who finds levels of around 40 per cent. But for Hertfordshire, Lincolnshire and Worcestershire 1550-1749, Overton finds that the value of capital goods (defined as furnaces, harrows, ladders, malt-mills, ploughs and gear, and spinning wheels) increases more than that of consumer goods (Overton, 2000). The value of animals increased about five- to sixfold in all four hundreds. ${ }^{18}$

The wealth of the farmers diversified in this period. Not one of the 120 had a bank account in 1800 - loans were informal - but in 1900 more than a third of farmers had savings in banks: three in Lagunda, eight in Sjuhundra, thirteen in Kullings and seventeen in Bara. In 1800 metal items and bed linen played an important role, ${ }^{19}$ but their importance had fallen by 1900 . Glass and porcelain were non-existent in 1800 but common in $1900 .{ }^{20}$ Furniture also became more important in 1900. The share who owned (registered) books fell from eighteen to eleven in Lagunda and from sixteen to eleven in Sjuhundra, but increased from one to seven in Bara, and from five to sixteen in Kullings. 
Table 5. Stock of animals in 1800 and 1900

\begin{tabular}{|c|c|c|c|c|c|c|c|}
\hline & & \multicolumn{6}{|c|}{$\begin{array}{c}\text { Mean \# } \\
\text { Median \# } \\
\text { Value }\end{array}$} \\
\hline & & Horses & Cattle & Sheep & Pigs & Geese & Hens \\
\hline \multirow[t]{6}{*}{ Sjuhundra } & 1800 & 3.0 & 5.2 & 7.0 & 4.3 & & 1.4 \\
\hline & & 3 & 5 & 6 & 4 & & 0 \\
\hline & & 31.5 & 32.2 & 7.1 & 6.5 & & 0.1 \\
\hline & 1900 & 3.5 & 9.7 & 3.5 & 1.8 & & 8.0 \\
\hline & & 3 & 7 & 3 & 1 & & 8 \\
\hline & & 257.0 & 250.7 & 14.1 & 25.7 & & 3.2 \\
\hline \multirow[t]{6}{*}{ Lagunda } & 1800 & 3.5 & 7.0 & 6.9 & 6.8 & 2.0 & - \\
\hline & & 3.5 & 6 & 5 & 5 & 0.5 & \\
\hline & & 41.7 & 37.7 & 7.4 & 7.2 & 0.7 & \\
\hline & 1900 & 2.9 & 11.8 & 2.4 & 2.9 & - & 21.1 \\
\hline & & 2.5 & 8.5 & 1.5 & 2 & & 15.5 \\
\hline & & 235.1 & 312.6 & 14.2 & 47.5 & & 5.4 \\
\hline \multirow[t]{6}{*}{ Bara } & 1800 & 6.0 & 5.1 & 7.8 & 8.0 & 3.5 & - \\
\hline & & 6 & 5 & 8 & 7 & 3 & \\
\hline & & 62.3 & 46.2 & 10.7 & 11.5 & 1.6 & \\
\hline & 1900 & 2.5 & 9.0 & 3.1 & 4.4 & 0.6 & 9.2 \\
\hline & & 2 & 6 & 2 & 2 & 0 & 0 \\
\hline & & 236.3 & 238.7 & 14.2 & 28.2 & 0.3 & 2.2 \\
\hline \multirow[t]{6}{*}{ Kullings } & 1800 & 1.6 & 8.4 & 9.8 & 2.9 & - & - \\
\hline & & 1 & 8 & 7.5 & 2 & & \\
\hline & & 14.5 & 33.1 & 3.9 & 1.4 & & \\
\hline & 1900 & 1.6 & 5.3 & 2.2 & 1.4 & - & 7.0 \\
\hline & & 1 & 4 & 2 & 1 & & 6 \\
\hline & & 93.8 & 131.1 & 8.5 & 23.8 & & 2.1 \\
\hline
\end{tabular}

Note: Value in 1800 SEK.

Table 5 shows the stock of animals in our four hundreds in 1800 and $1900 .^{21}$ The number of horses stagnated or decreased over the century, while the number of cattle increased in each hundred except Kullings, where the number was already very high. This highlights the reduced need for draught animals with improved ploughs and harrows, and the increase in dairy production. In Sjuhundra in 1900, twenty of the twenty-seven investigated farmers owned threshers. Only one owned a mower (slåttermaskin) but this was more common in Lagunda. Threshers were widespread in Bara, too, as were harvesters (skördemaskin) and sowing machines (såningsmaskin). Horse rakes (hästräfsa) were common in the mid-Swedish hundreds as well as in Bara. The declining number of animals is in line with Gadd's investigation (1983: 119-20) over the 1750-1850 period, where the number of oxen in his West Swedish investigation area halved from about four to about two per farm over a hundred years, and the number of sheep decreased from 9.8 to 6.8 . Beyond increased mechanisation, another reason for the decreasing size of animal stock was the 
growth in size, strength and yield per animal (Olsson 2005: 129-30). Despite the fact that the number of animals decreased, the value of the animals increased - for the horses by five to eight times in our four hundreds. This indicates the increasing strength of each animal, as well as the increased profitability for the agricultural produce. Threshers were the most common machine, followed by mowers and horse rakes; this accords rather well with Kuuse's (1970: 49-50) findings for Uppland in 1890 and 1910. It also reflects the desire to save labour during increased competition in this area with industry, targeting the most labour-intensive tasks in agriculture: harvesting and threshing (Morell, 2001: 195-7). The farmers in our sample were better equipped than the farmers from the relatively poor region of Kronoberg in Kuuse's (1970: 51-2) sample, where almost no farmers owned harvesters, and movers and horse rakes also were uncommon; only threshers were common among the Kronoberg farmers.

Table 5 shows that Swedish farmers grew wealthier over the nineteenth century but not necessarily by getting larger farms and more animals. Instead, increased land values (see Table 4) because of (a) growing productivity (Olsson and Svensson, 2010) and (b) more market demand from cities and the export sector meant that ordinary farmers by 1900 could be quite well off. At the same time, inequality grew rapidly in the rural sector, both because of proletarianisation (see Table 2) and, within the farmer class, because of the growth of very small farms and because of the lagging growth in the peripheral regions.

\section{Conclusions}

Economically, Swedish peasant farmers were a rather homogenous and equal group in 1750 . During the next 150 years, however, stratification within the group increased. Farmers became more wealthy everywhere, but the growth in living standards was unequally distributed over the country. Those who benefited more than others were farmers in locations close to the major cities, harbours and railroads, and farmers on more productive soil. With the growing demand for agricultural products in cities and abroad, farmers who were well placed in terms of natural conditions and in terms of geography and infrastructure benefited immensely. This regional difference has been missed by the previous, very locally focused literature.

We have illustrated the uneven wealth accumulation by a close study of farmers in four well-off hundreds. This in-depth study has shown the importance of the great growth of land values, connected to the increasing demand for agricultural produce, and the increased productivity connected to stock-raising and early mechanisation. Here we must consider that the number of farmers with exceedingly small farms grew considerably in the nineteenth century. According to Wohlin (1912: 788-99), the share of farms with less than 1/8 mantal for middle and southern Sweden was 25.5 per cent in 1840 and 35.9 per cent in 1865; the share grew further in the last third of the century. This increased inequality within the farmer class, and created a class of hybrid farmer-workers who had to work for wages (in sawmills, building roads, etc.). But in certain regions, one could probably also live off smaller farms with increased productivity and profitability per unit.

For further research, one key task is to map wealth accumulation and distribution in some poorer regions. In our in-depth study, we deliberately focused on four wealthy areas, to grasp the process of wealth accumulation where it was most intense. Studying poorer, more remote areas - such as those labelled 'inland', 'forest' or 'north' in the regional study here - in the nineteenth century, and especially over the second half of it, with the approach used here would yield new insights into the fate of the farmer class in this very dynamic period. The static focus on the farmer class per se used in this study should then also ideally be combined with a focus on entry into and exit from the farmer class, that is, mobility to the cities and social mobility into the proletarian and semi-proletarian groups (as in Winberg, 1975). The aggregate focus of most of this article prevents us from going into such detail, but new local/regional studies could make use of 
this national study for context and combine its macro insights with the sensitivity to the local and fine-grained analysis made possible by a more local design. It would then be interesting to know whether the share of farmers in the population shrank more rapidly where farmers' wealth accumulation was slower than in other areas, if social mobility downwards was more common, and if emigration was more common. This study has provided a piece of the puzzle in understanding the well-being and personal economics of the Swedish farmer class over the 1750-1900 period, but certainly more studies are needed.

Acknowledgements. This article was presented at the conference of the Social Science History Association, Chicago, in November 2016; the Economic History Society annual conference, London, 31 March-2 April 2017; a workshop in Uppsala in June 2017 and at the Rural History conference in Leuven, in September 2017. We are grateful to all the participants and especially to Håkan Lindgren, our discussant in Uppsala, for comments. Work on the article has been financed by grants from Handelsbankens forskningsstiftelser and the Swedish Research Council.

\section{Notes}

1 See Hall (2000), especially pp. 118-25, 163-4, 215-17, 242-3 on the importance of the farmer figure for Swedish nationalism and history writing.

2 The peasant farmers constituted a social class defined by (a) their cultivation of taxed land and (b) their non-noble status. 3 That many farmers were tenants rather than freeholders is indicated by the discrepancy between the share of land held by farmers, and the share tilled by farmers. In 1700 , about 85 per cent of the land was worked by peasant farmers, and in 1845 , it was 80 per cent (Gadd, 2000).

4 With Wohlin's data, which goes back to 1750, it is not possible to compare 1750 with later years, because the sources are not the same, and even for the latter period, it is a little unclear what sources are used and whether the years are fully comparable. See (Winberg, 1975: 180).

5 We end up with thirty-seven districts instead of the original thirty-two.

6 These are: (1) Nobility; (2) Factory owners; (3) Clergy; (4) Persons of rank; (5) Teachers and students; (6) Bourgeoisie; (7) Farmers; (8) Rural artisans; (9) Tradesmen; (10) Crofters; (11) Healthcare workers; (12) Soldiers; (13) Other in towns; (14) Cottagers; (15) Workers in factories and (16) Servants/labourers. We then merge these into four main groups: Nobility (1); Bourgeoisie $(2+3+4+5+6+9)$; Peasant farmers (7); and Workers and lower middle class $(8+10+11+12+13+14+15+16)$. 7 In reality, crofters also often held and cultivated land. In some regions crofts could be as large as small peasant farms. However, crofters lacked the social standing of the peasant farmer class, for example, political representation, and are not studied explicitly in this study (see our discussion and definition of the peasant-farmer class above).

8 We have also worked out the calculations using Lindgren's proposed adjustment upwards by 100 per cent in 1850 . This does not make much difference to estimates of inequality (for example, Tables 1 and 2), but does smooth out the growth of wealth 1800-1900 (Tables 3 and 4), so that more of it occurs from 1800 to 1850 .

9 Most of the English debate is about dispossession, enclosures and whether English farmers owned any land at all. Finlay's (2001) overview of newer German agrarian history says nothing about quantitative inequality estimates.

10 One could argue that we are mixing apples and oranges by looking at the farmer class as a whole, that is, including old retired people along with active farmers. Using the Waldenström adjustments, 1800 prices, and only looking at people of 25-59 years of age, the average wealth for all farmers is $452 \mathrm{kr}$ in 1800, $735 \mathrm{kr}$ in 1850 and $1505 \mathrm{kr}$ in 1900 . In other words, an age adjustment makes very little difference and does not change the trend.

11 A 'hundred' is an administrative county division that is geographically part of a larger region.

12 The plains hundreds are Kullings, Skärkinds, Ale, Valkebo and Bara, all in the southern part of Sweden. The Stockholm and iron hundreds are Sjuhundra, Norrbo, Söderbärke, Våla, Folkare, Simtuna and Lagunda, all in the Stockholm region and central region. The inland hundreds are Vista in the south, Sundbo and Kils in Svealand, and Bygdeå in the north. The coastal hundreds are Bjäre, Östra, Himle, Faurås, Inlands Torpe and Inlands Södre in the south and on the west coast. The northern hundreds are Arvidsjaurs, Piteå, Enångers, Delsbo and Våla, all in the north. The forest hundreds are Norra Vedbo, Hova, Kinds, Ydre and Kinnevalds, all in the southern parts of the country.

13 A closer look at the inventories from northern Sweden in 1800 reveals that the farmers had large stocks of cattle and/or reindeer and that in some cases tar and timber constituted a significant contribution to overall wealth. It was also relatively common to find cash in these inventories, as compared to other regions.

14 We define an 'active' farmer in the probate inventories as one who had draught animals as well as tools at the time of his/her death.

15 The farmers' wealth here can be compared to Sundbärg's (1910, Table 67) wealth per person data. According to Sundbärg, average (taxed) real estate wealth per person in Sjuhundra in 1907 was 827 kr, in Lagunda 1229 kr, in Kullings 693 kr, and in Bara $1734 \mathrm{kr}$. 
16 The general trend, based on the results in Table 4, is in accordance with the development shown in Wohlin (1911, tabellbilaga G) for the hundreds. Here taxed property values during 1813-1900 increase by 217 per cent in Sjuhundra, by 223 per cent in Lagunda, by 536 per cent in Kullings and by 728 per cent in Bara. The reason we get very large increases in mean land prices for Kullings and Bara is the fact that market values are not proportional to the mantal concept, or to the size of land; smaller units have a higher value per mantal and as discussed above farms were split in these hundreds and smallholders formed the majority of farmers there in 1900 (see Svensson, 2001: 62-6 and 261-3 for a discussion on land prices and size of farms).

17 Notably, in the inventory of one of the active Bara farmers, the forty-two-year-old tenant Anders Persson, the standard category of 'ploughing tools' (åkerredskap) was complemented by the novel category of 'machinery' (maskiner). This included a seeder (såningsmaskin) and a thresher (tröskverk).

18 There are regional differences in the kinds of animals they held. In Kullings the cattle held a larger share, while horses were more important in Bara. This difference is in line with what Gadd (2000: 170) says about the western plains.

19 The relatively high value of the bed linen accords well with Gadd's (2000: 64) point that expensive bed linen worked as eye-catching status consumption in Sweden's eighteenth-century agrarian society.

20 Rosén (2004: 245) finds that in the eighteenth century most people in Halland had only wooden vessels, while the wealthy also had tin cups, etc. During the nineteenth century, porcelain starts to appear in the probate inventories there.

21 We have not delved into the development of crops, since the results are very much in line with what we would expect from the previous literature. A cursory inspection of the crops and grains in the inventories from Bara and Kullings reveals that in Bara, rye and barley became relatively less important while oats and wheat became more important, as did non-grain produce such as sugar beets and potatoes. In Kullings, oats were quite dominant in 1900 (62 per cent of the value of grains in the inventories, as compared to 17 per cent in 1800), while rye was central in 1800. Sugar beets were not grown in Kullings, but potatoes were an important part here too. The results are in line with available statistics for overall production of Swedish agriculture in the nineteenth century, and the differences between the south (such as Bara) and the rest of the country. See (Fogelfors, 1997: 66-81; Morell, 2001: 203-13.

\section{References}

Ågren, Maria. 1992. 'Jord och gäld: Social skiktning och rättslig konflikt i södra Dalarna ca 1650-1850', PhD (Uppsala). Allen, Robert C. 1992. Enclosure and the Yeoman (Oxford).

Allen, Robert C. 2009. The British Industrial Revolution in Global Perspective (Oxford).

Aronsson, Peter. 1992. 'Bönder gör politik: Det lokala självstyret som social arena i tre smålandssocknar, 1680-1850', PhD thesis in history (Lund).

Atack, Jeremy and Fred Bateman. 1981. 'Egalitarianism, inequality, and age: the rural North in 1860', Journal of Economic History, 41:1, 85-93.

Bengtsson, Erik, Anna Missiaia, Mats Olsson and Patrick Svensson. 2018. 'Wealth inequality in Sweden, 1750-1900', The Economic History Review, 71:3, 772-94.

Bengtsson, Erik, Anna Missiaia, Mats Olsson and Patrick Svensson. 2019. 'Aristocratic wealth and inequality in a changing society: Sweden, 1750-1900', Scandinavian Journal of History, 44: 27-52.

Bengtsson, Tommy, Mats Olsson and Patrick Svensson. 2011. 'Inequality and Economic Development in Sweden, 1700-1930: A Microeconomic Approach' (Lund).

Bergenfeldt, Fredrik, Mats Olsson and Patrick Svensson. 2013. 'Wagons at work, or a transport revolution from below: the case of southern Sweden, 1750-1850', The Agricultural History Review, 61:1, 63-82.

BiSOS. 1895. Bidrag till Sveriges Officiela Statistik (1895) N) Jordbruk och boskapsskötsel, Tab. B. (Stockholm).

Dribe, Martin and Christer Lundh. 2005. 'Retirement as a strategy for land transmission: a micro study of pre-industrial rural Sweden', Continuity and Change, 20:2, 165-91.

Edvinsson, Rodney. 2010. 'Foreign Exchange Rates in Sweden 1658-1803', in Rodney Edvinsson, Tor Jacobson and Daniel Waldenström, eds, Exchange Rates, Prices, and Wages, 1277-2008 (Stockholm), 238-90.

Edvinsson, Rodney and Johan Söderberg. 2010. 'The Evolution of Swedish Consumer Prices, 1290-2008', in Rodney Edvinsson, Tor Jacobson and Daniel Waldenström, eds, Historical Monetary and Financial Statistics for Sweden: Exchange Rates, Prices and Wages, 1277-2008 (Stockholm), pp. 412-52.

Erikson, Marja. 2018. 'Krediter i lust och nöd: Skattebönder i Torstuna härad, Västmanlands län, 1770-1870', PhD thesis in Economic History (Uppsala).

Finlay, Mark. 2001. 'New sources, new theses, and new organizations in the New Germany: recent research on the history of German agriculture', Agricultural History, 75:3, 279-307.

Fogelfors, Håkan. 1997. 'Uppkomst och förädling av svenskodlade kulturväxter', in Bengt, M. P. Larsson, Mats Morell and Janken Myrdal, eds, Agrarhistoria (Stockholm), pp. 66-81.

Gadd, Carl-Johan. 1983. 'Järn och potatis: jordbruk, teknik och social omvandling i Skaraborgs län 1750-1860', PhD thesis (Gothenburg).

Gadd, Carl-Johan. 2000. Den agrara revolutionen 1700-1870, Det svenska jordbrukets historia, III (Stockholm). 
Gadd, Carl-Johan. 2011. 'The Agricultural Revolution in Sweden, 1700-1870', in Myrdal, Janken and Mats Morell, eds, The Agrarian History of Sweden: 4000 BC to AD 2000 (Lund), pp. 118-64.

Hall, Patrik (2000), Den svenskaste historien: Nationalism i Sverige under sex sekler (Stockholm).

Hallén, Per. 2003. 'Järnets tid: Den svenska landsbygdsbefolkningens järninnehav och järnkonsumtion 1750-1870', PhD thesis in Economic History (Gothenburg).

Heckscher, Eli. 1941. Svenskt arbete och liv: Från medeltiden till nutiden (Stockholm).

Herlitz, Lars. 1974. 'Jordegendom och ränta: Omfördelningen av jordbrukets merprodukt i Skaraborgs län under frihetstiden', PhD thesis in Economic History (Gothenburg).

Hoppe, Göran and John Langton, 1994. Peasantry to Capitalism: Western Östergötland in the Nineteenth Century (Cambridge).

Isacson, Maths. 1979. 'Ekonomisk tillväxt och social differentiering 1680-1860: Bondeklassen i By socken, Kopparbergs län', $\mathrm{PhD}$ thesis (Uppsala University).

Kuuse, Jan. 1970. Från redskap till maskiner: mekaniseringsspridning och kommersialisering inom svenskt jordbruk 1860-1910 (Gothenburg).

Kuuse, Jan. 1974. 'The probate inventory as a source for economic and social history', Scandinavian Economic History Review, 22:1, 22-31.

Köll, Anu-Mai. 1983. 'Tradition och reform i västra Södermanlands jordbruk 1810-1890: Agrar teknik i kapitalismens inledningsskede', $\mathrm{PhD}$ thesis (Stockholm).

Lilja, Kristina, Sofia Murhem and Göran Ulväng. 2007. 'Auktionshandeln i stad och på landsbygd: Varucirkulation i Enköping med omnejd under 1700- och 1800-talen’, in Ahlberger, Christer and Pia Lundqvist, eds, Varans vägar och världar: Handel och konsumtion i Skandinavien ca 1600-1900, Skrifter från Historiska institutionen i Göteborg, 9 (Gothenburg).

Lindgren, Håkan. 2002. 'The modernization of Swedish credit markets, 1840-1905: evidence from probate records', Journal of Economic History, 62:3, 810-32.

Lindgren, Håkan. 2017. 'Om fastighetsvärderingar i svenska bouppteckningar under 1800-talet', paper presented at the Swedish Economic History Meeting, Stockholm, 12 ${ }^{\text {th }}$ to $14^{\text {th }}$ October 2017 (Stockholm).

Lindström, Jonas. 2008. 'Distribution and Differences: Stratification and the System of Reproduction in a Swedish Peasant Community 1620-1820', PhD thesis (Uppsala).

Lundh, Christer. 1999. 'The social mobility of servants in rural Sweden, 1740-1894', Continuity and Change, 14:1, 57-89.

Löfgren, Orvar. 1977. Fångstmän i industrisamhället: en halländsk kustbygds omvandling 1800-1970 (Lund).

Markkanen, Eero. 1978. 'The use of probate inventories as indicators of personal wealth during the period of industrialization: the financial resources of the Finnish rural population, 1850-1911', Scandinavian Economic History Review, 26:1, 66-83.

Martinius, Sture. 1977. Peasant Destinies: The History of 552 Swedes Born 1810-12 (Stockholm).

Milanovic, Branko, Peter H. Lindert and Jeffrey G. Williamson. 2011. 'Pre-industrial inequality', The Economic Journal, 121: 255-72.

Morell, Mats. 1980. 'On the stratification of the Swedish peasant class', Scandinavian Economic History Review, 28:1, 15-32.

Morell, Mats. 2001. Jordbruket $i$ industrisamhället: 1870-1945 (Stockholm).

Olausson, Peter. 2004. 'Rikedom, makt och status i bondesamhället: Social och ekonomisk skiktning i västra Värmland från 1600-talet till 1800-talets mitt', PhD thesis (Karlstad).

Olsson, Mats. 2005. Skatta dig lycklig: Jordränta och jordbruk i Skåne 1660-1900 (Hedemora).

Olsson, Mats and Patrick Svensson. 2010. 'Agricultural growth and institutions: Sweden 1700-1860', European Review of Economic History, 14:2, 275-304.

Olsson, Mats and Patrick Svesson. 2016. 'The landlord lag - productivity on peasant farms and landlord demesnes during the agricultural revolution in Sweden 1700-1860', Scandinavian Economic History Review, 64:1, 55-71.

Overton, Mark. 2000. 'Prices from Probate Inventories', in Arkell, Tom, Nesta Evans and Nigel Goose, eds, When Death Do Us Part: Understanding and Interpreting the Probate Records of Early Modern England (Oxford), pp. 120-43.

Overton, Mark. n.d. 'Household Wealth, Indebtedness, and Economic Growth in Early Modern England' (Exeter).

Pfister, Ulrich and Michael Kopsidis, 2015. 'Institutions versus demand: determinants of agricultural development in Saxony, 1660-1850', European Review of Economic History, 16: 275-93.

Rosén, Christina. 2004. 'Stadsbor och bönder: Materiell kultur och social status i Halland från medeltid till 1700-tal', PhD thesis in Archaeology (Lund).

Schön, Lennart. 1979. Från hantverk till fabriksindustri: Svensk textiltillverkning 1820-1870 (Lund).

Schön, Lennart. 2012. An Economic History of Modern Sweden (London).

Sjöberg, Maria. 2003. 'Marknad, bönder och kön: En fråga om likhet och skillnad', Historisk tidskrift, 123: 299-315.

Söderberg, Johan. 1993. Civilisering, marknad och våld i Sverige 1750-1870: en regional analys (Stockholm).

Soltow, Lee. 1971. Patterns of Wealthholding in Wisconsin since 1850 (Madison, MA and London).

Sundbärg, Gustav. 1910. Ekonomisk-statistisk beskrifning öfver Sveriges olika landsdelar, Emigrationsutredningen, Bilaga V (Bygdestatistik and Stockholm). 
Svensson, Patrick. 2001. 'Agrara entreprenörer. Böndernas roll i omvandlingen av jordbruket i Skåne ca. 1800-1870', PhD in Economic History (Lund).

Svensson, Patrick. 2006. 'Peasants and entrepreneurship in the nineteenth-century agricultural transformation of Sweden', Social Science History, 30:3, 387-429.

Svensson, Patrick. 2013. 'Land Market, Property Rights, and Agricultural Transformation in Southern Sweden, 1680-1870', in Béaur, G., P. R. Schofield, C.-M. Chevet and M.-T. Perez Picazo, eds, Property Rights, Land Markets, and Economic Growth in the European Countryside (Thirteenth - Twentieth Centuries) (Turnhout), pp. 455-73.

Söderberg, Johan. 1993. Civilisering, marknad och våld $i$ Sverige 1750-1870: En regional analys, Stockholm Studies in Economic History, 18 (Stockholm).

Tengroth Ulväng, Marie. 2007. 'Bondehushåll i förändring: Kläder som uttryck för socioekonomisk ställning i 1800-talets Härjedalen', in Ahlberger, Christer and Pia Lundqvist, eds, Varans vägar och världar: Handel och konsumtion $i$ Skandinavien ca 1600-1900, Skrifter från Historiska institutionen i Göteborg, 9 (Gothenburg), 57-74.

Utterström, Gustaf. 1957. Jordbrukets arbetare: Levnadsvillkor och arbetsliv på landsbygden från frihetstiden till mitten av 1800-talet. Första delen (Stockholm).

Waldenström, Daniel. 2017. 'Wealth-income ratios in a small, developing economy: Sweden, 1810-2014', Journal of Economic History, 77:1, 285-313.

Van Zanden, Jan Luiten. 1995. 'Tracing the beginning of the Kuznets Curve: western Europe during the early modern period', Economic History Review, 48:4, 643-64.

Wiking-Faria, Pablo. 2009. 'Freden, friköpen och järnplogarna: drivkrafter och förändringsprocesser under den agrara revolutionen i Halland 1700-1900', PhD thesis (Gothenburg).

Winberg, Christer. 1975. 'Folkökning och proletarisering: kring den sociala strukturomvandlingen på Sveriges landsbygd under den agrara revolutionen', PhD thesis (University of Gothenburg).

Wohlin, Nils. 1909. Den jordbruksidkande befolkningen i Sverige 1751-1900, Emigrationsutredningen, bilaga IX (Stockholm).

Wohlin, Nils. 1911. Emigrationsutredningen bilaga XII: Jordstyckningen (Stockholm).

Wohlin, Nils. 1912. 'Den svenska jordstyckningspolitiken i de 18: e och 19:de århundradena jämte en öfversikt af jordstyckningens inverkan på bondeklassens besutenhetsförhållanden', $\mathrm{PhD}$ thesis (Stockholm).

Yang, Donghyu. 1984. 'Notes on the wealth distribution of farm households in the United States, 1860: a new look at two manuscript census samples', Explorations in Economic History, 21: 88-102.

Cite this article: Bengtsson E and Svensson P (2019). The wealth of the Swedish peasant farmer class (1750-1900): composition and distribution. Rural History 30, 129-145. https://doi.org/10.1017/S0956793319000116 